\title{
SMART SCHOOL MANAGEMENT SYSTEM OF PRESENCE MONITORING TEACHER AS A REALTIME WITH RAD (RAPID APPLICATION DEVELOPMENT) METHOD AT KHADIJAH HIGH SCHOOL SURABAYA
}

\author{
${ }^{1}$ RAHMAWATI FEBRIFYANING TIAS, ${ }^{2}$ MAS NURUL HAMIDAH, ${ }^{3}$ ARIF ARIZAL, ${ }^{4}$ FARDANTO \\ SETYATAMA \\ Informatics Engineering University of Bhayangkara \\ Surabaya, Indonesia

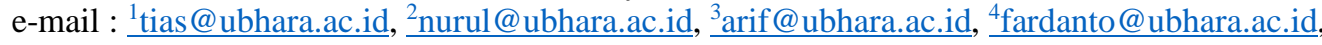

\begin{abstract}
This research create an application for monitoring the presence of teachers when carrying out teaching activities in real time at Khadijah High School Surabaya. The method that will be used in making this application is to use the RAD (Rapid Application Development) method. The RAD method is an application development process based on prototyping, iteration, and repeated feedback. That way the applications that are made can be developed and repaired quickly and are in accordance with the needs and developments of the super-fast digital world. The process of testing this application is carried out by simulating the teaching and learning process carried out by the teacher and monitored directly by the principal in real time. Smart school management system application as a realtime monitoring of teacher attendance using the RAD (Rapid Application Development) method at SMA Khadijah Surabaya. The results of this study are very useful for school principals to monitor teachers in teaching and learning activities at Khadijah High School Surabaya and also make it easier for teachers to make attendance at teaching and learning activities every time.
\end{abstract}

Keywords: Smart School Management System, Presence Monitoring Teacheru, RAD Method.

\section{INTRODUCTION}

The development of technology in the digital era is increasingly rapid, with the discovery of new methods and creative ideas, more and more applications are created that are very useful to facilitate activities in various fields. In the field of education, the author creates a smart school management system application as a real-time monitoring of teacher attendance using the RAD (Rapid Application Development) method. It aims to improve the quality, efficiency, and effectiveness of performance, and is useful for improving the quality of education and information services at SMA Khadijah Surabaya, as well as an effort to be able to compete in the era of the industrial revolution 4.O.

In this case, the school prepares itself by developing a smart school management system service to make it easier for everyone to access the services provided by the school. This smart school application can be accessed using a mobile device or computer because it is based on Android and the website. Smart School System or smart school is a school concept that utilizes information technology in teaching and learning activities and school administration. Smart School consists of various systems that are integrated with each other, which are used by school residents according to their respective roles, both students, teachers, and school staff.

As for the method used in making this smart school management, the author uses the RAD (Rapid Application Development) method. RAD is a software process model that emphasizes a short development life cycle. RAD is a quick adaptation version of the waterfall model, using a component construction approach . RAD is a combination of various structured techniques with prototyping techniques and joint application development techniques to accelerate system/application development. From the definition of the RAD concept, it can be seen that application development using the RAD method can be done in a relatively faster time. In accordance with the RAD methodology, the following are the application development stages of each application development phase. 


\section{METHOD}

The smart school management system applications as monitoring teacher attendance in real time with the RAD (Rapid Application Development) method. In this study, the authors chose the Rapid Application Development (RAD) method because the stages are structured and the making of smart school management applications can be done in a fast time, the results made can be known without waiting a long time because the process is divided into several modules. and the main reason for using the Rapid Application Development (RAD) development method is that this development method will work well if applied to small-scale applications. The stages of the Rapid Application Development (RAD) method are:

\section{a. Requirements Analysis Phase}

This phase has the objective of identifying the services, limitations, and objectivity of the system by collecting data at Khadijah high school Surabaya.

\section{b. Modeling Analysis Phase}

The purpose of the modeling analysis phase is to analyze all activities in the overall system architecture by involving the identification and description of the underlying application system abstractions and interrelationships between systems.

\section{c. Modeling Design Phase}

The purpose of the modeling design phase is to design a system based on the analysis that has been done previously. The analysis and design stages are repeated until a system design that truly meets the needs of Khadijah High School Surabaya is obtained. In this Smart school management application, the researcher makes using PHP Framework CI and database design using MySQL.

\section{d. Construction Phase}

The purpose of the construction phase is to show the platform or application used and the limitations in implementation, test the performance of the smart school management application that has been built so that it can be seen whether the application is in accordance with the analysis and design specifications that have been identified previously. The final result of the construction phase is a performance test or performance stability and the feasibility of the application that has been made.

\section{RESULT AND IMPLEMENTATION}

\section{A. SYSTEM ANALYSIS}

The RAD (Rapid Application Development) method is a software model that emphasizes short development. RAD is an adaptation of the waterfall model, using a component construction approach. RAD is a combination of various structured techniques with prototyping techniques and joint application development techniques to accelerate system development. From the definition of the RAD concept, it can be seen that application development using the RAD method can be done in a relatively faster time. In accordance with the RAD methodology, the following are the application development stages of each application development phase which can be seen in Figure 1.

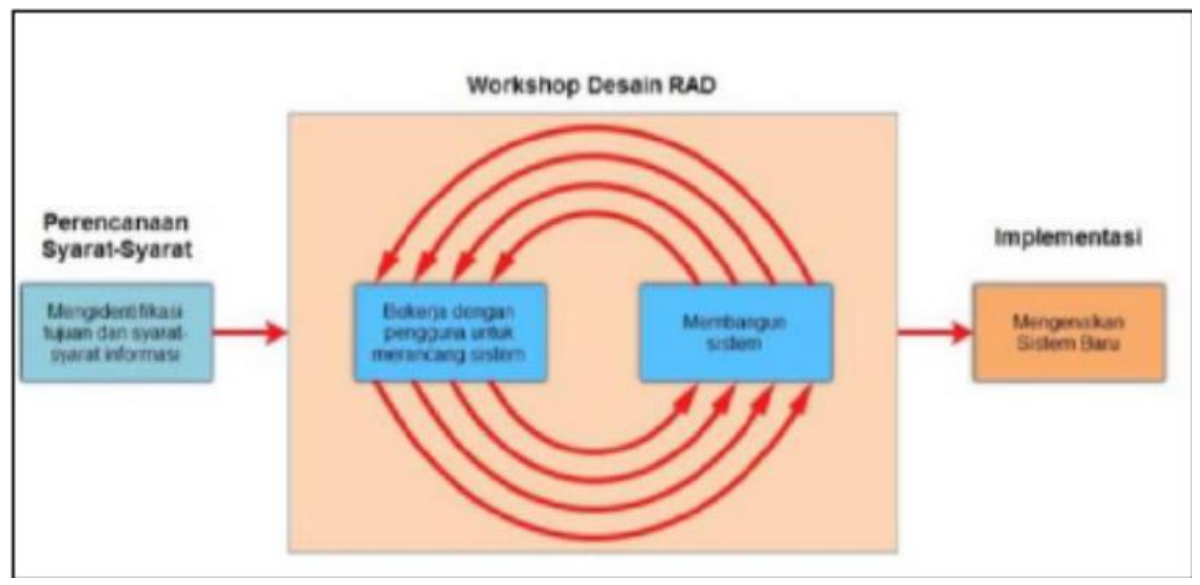

Figure 1. RAD (Rapid Application Development) System. 


\section{B. OBJECT IMPLEMENTATIONS}

The results of the implementation of the smart school management system application as real-time monitoring of teacher attendance using the RAD (Rapid Application Development) method include the admin page, where the admin is the control center in managing the smart school management application, while the admin page display as shown in Figure 2 .

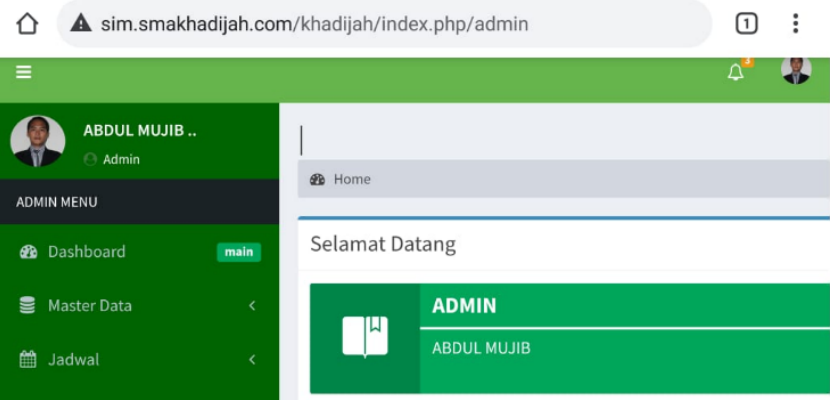

Figure 2. Dashboard Admin

In this case, the researcher makes menus and sub menus on the admin page according to the management needs at Khadijah High School Surabaya, including management for master data, setting teaching and learning schedules, student assessments, attendance reports, etc. as shown in the Figure. 3.

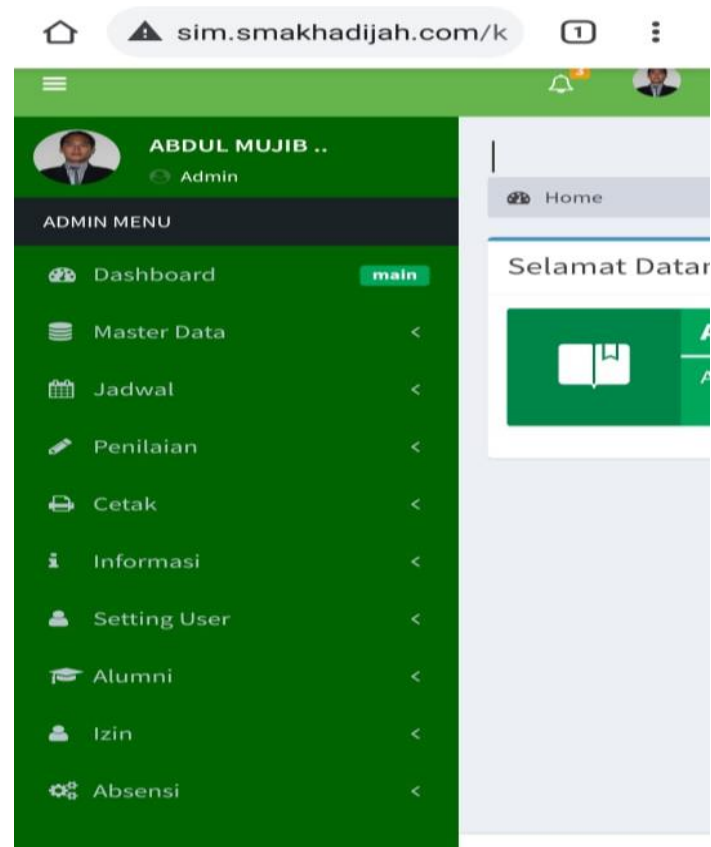

Figure 3. Menu and Sub Menu Admin

In addition to the admin menu, the researchers also created a menu for teachers, where teachers can also manage several menus according to the performance needs of teachers at Khadijah High School Surabaya, on the teacher menu there is a menu to view the schedule of teaching and learning activities along with a calendar of academic activities for one year, as in figure 4. 


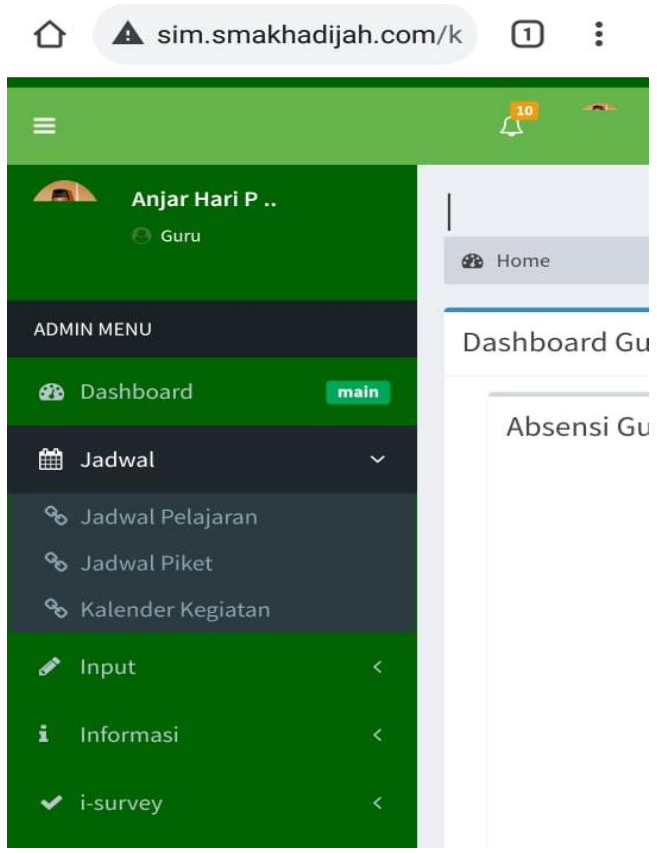

Figure 4. Dashboard Teacher

In addition to the schedule menu on the teacher's page, there is also an input menu, where in the input menu there are sub menus in the form of violations of rules, complaints about infrastructure, teacher permission, and assessments. For the input sub menu for violations of the rules, the teacher can make input if he sees a student committing a violation of the rules, which later the input can be immediately seen by the counseling guidance party, for the input menu for infrastructure, the teacher can input if you want to give suggestions or complaints about School facilities and infrastructure that are deemed inadequate should immediately receive good treatment, in order to maintain the quality and quality of Khadijah High School Surabaya.

In the input sub menu, the teacher's permission is input if the teacher is unable to attend the teaching and learning process so that it will be directly integrated into the teacher's attendance. And the assessment input sub menu on the teacher's page can be done systematically, not manually anymore, so that later it can be directly archived to each student. From all the descriptions of the input menu on the teacher's page that the researcher describes, it can be seen in Figure 5.

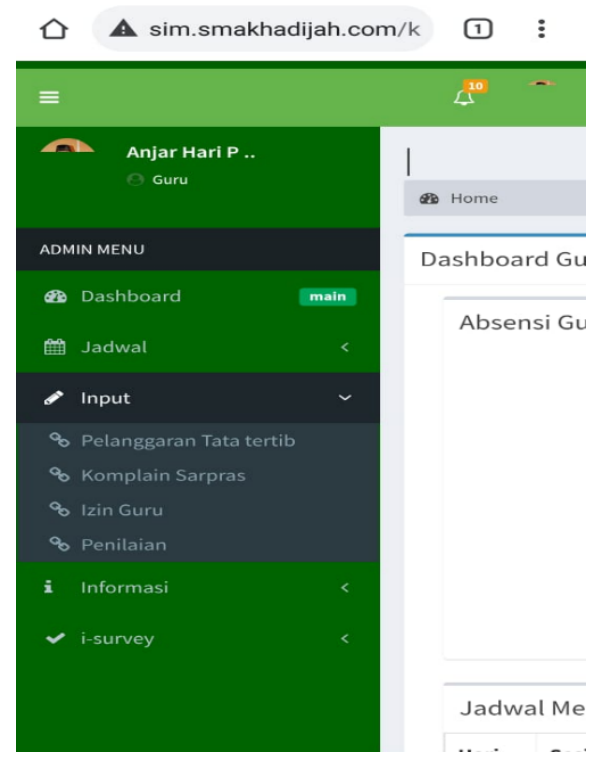

Figure 5. Input Menu Dashboard Teacher 
The information menu on the teacher's page consists of several sub menus, namely the attendance of the teaching and learning process, the attendance of payroll deductions, teacher announcements and assignment letters, all the menus on the teacher's page are integrated with each other At Khadijah High School Surabaya, teacher attendance is carried out using fingerprints and the management is done in real time which is directly integrated with the smart school management application.

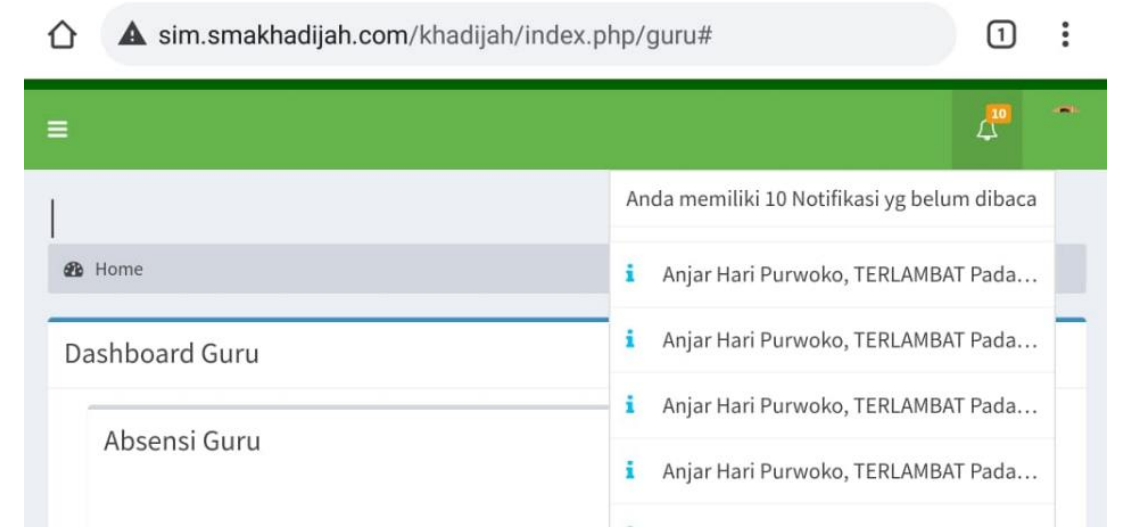

Figure 6. Presence Notification Teacher

The flow of the teacher attendance monitoring system in this smart school management application is that the teacher performs an attendance. the teaching and learning process but is not present or experiencing delays, a notification of absenteeism or late attendance of the teacher will appear as shown in Figure 6. and the report is directly integrated into the payroll deduction menu in accordance with the applicable policies at Khadijah High School Surabaya. As shown in Figure 7.

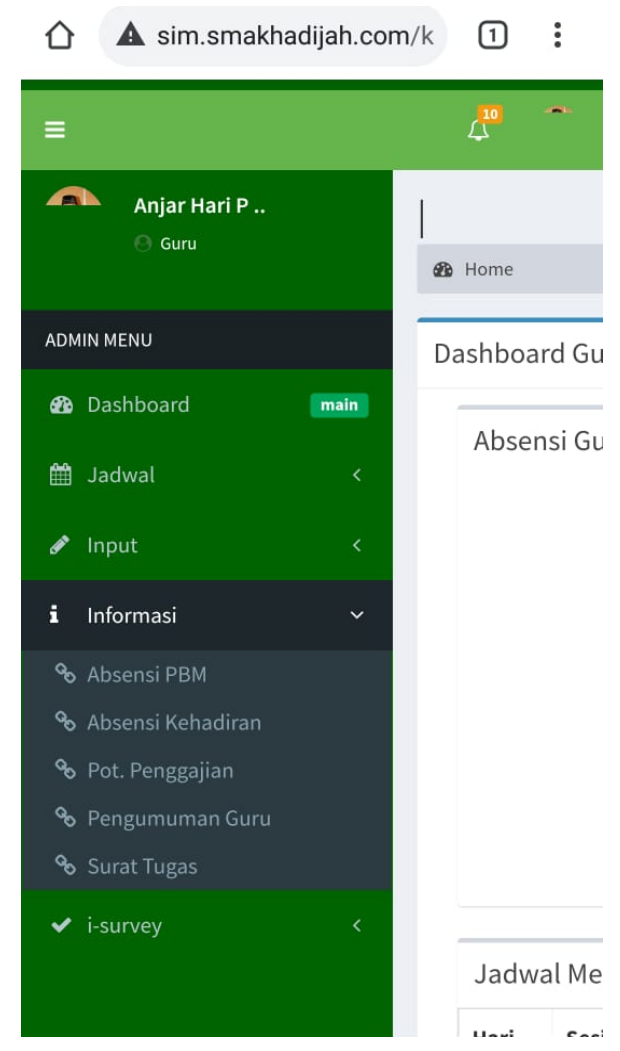

Figure 7. Information Menu 


\section{CONCLUSION}

The smart school management system application as a real-time monitoring of teacher attendance with the RAD (Rapid Application Development) method is one of the future school management system models that is carried out systematically and structured with very useful features to facilitate the performance of teachers and can create a learning environment that is conducive to learning. creative, interactive, effective, efficient and paperless.

The smart school management system application as a real-time monitoring of teacher attendance with the RAD (Rapid Application Development) method is able to create a management system that can support improving school quality.

\section{REFERENCES}

[1]. He. An Understanding Information Management System for a Real-Time Interactive Distance Education Environment. International Journal of Distance Education Technologies, ISSN: 1539-3100, Vol. 7, No. 1. 2009.

[2]. Mingsep S. Desain Aplikasi Smart School Sebagai Model Pembelajaran Inovatif. Program Studi Sistem Informasi FMIPA. Universitas Cendrawasih. 2017.

[3]. Akhmad Sofwan. Belajar PHP dengan Framework Code Igniter. Ilmu Komputer.com. 2007.

[4]. A. Rini, F. Fatmariani. Penerapan Metode RAD Pada Sistem Pengajuan Pengambilan Data Penelitian Bankesbangpol Kota Aiguo Palembang. Jurnal TI Atma Luhur, Vol. 4, pp. 1-12, 2017.

[5]. Meidyan P., Hendra E. Implementasi Metode Rapid Application Development Pada Website Service Guide "Waterfall Tour South Sumatera". Jurnal SISFOKOM, Vol. 07. No. 2. September 2018 